\title{
HISTORICAL PERSPECTIVES ON AMERICAN IMMIGRATION POLICY: CASE STUDIES AND GURRENT IMPLICATIONS
}

\author{
Maxine S. SelleR*
}

\section{INTRODUCTION}

With close to 1,000,000 legal and illegal immigrants entering the United States every year and additional would-be immigrants from Cuba, Haiti, El Salvador, and elsewhere clamoring for admission, immigration policy has emerged as an important issue for the 1980's. How many should be admitted? Should preference be given to persons with skills needed in the current economy or to refugees?-and who is a "refugee"? Will today's Third World immigrants have a harder time adjusting to America than their earlier, European counterparts? Are immigrants taking jobs from American citizens? These and other questions are being raised by the media daily.

Immigration policy involves value judgments about the motivation and potential contributions of particular individuals and groups, the probable ease of their adjustment to America and of America's adjustment to them, and the political, social, and economic consequences of admitting them-or the moral consequences of not admitting them. The issues are complex, but they are not new.' Debates about immigration policy began with the establishment of the Thirteen Colonies and have continued, at varying levels of intensity, to the present. Knowledge of the history of these debates will not provide instant answers to the dilemmas of the 1980's, but such knowledge can inform our own debates and, at least, warn us of possible pitfalls.

This article first will review scholarship outlining the major arguments raised repeatedly by both sides in immigration policy debates throughout our history. It will then analyze the use of these arguments and their resolution in immigration policy in three specific historical situations: the early 18th century, the decades

\footnotetext{
Copyright (C) 1983 by Law and Contemporary Problems

* Professor, Department of Educational Organization, Administration and Policy, State University of New York at Buffalo.

1. For an introduction to immigration history, see generally L. DiNNERSTEIN \& D. REIMERS, ETHNIC Americans: A History of Immigration and Assimilation (1975); M. Hansen, The Atlantic Migration 1607-1860 (1940); M. Seller, To Seek America: A History or Ethnic Life in the United States (1977); P. Taylor, The Distant Magnet: European Immigration to the U.S.A. (1971); Reimers, Post-World War II Immigration to the United States: America's Latest Newcomers, in AMERICA AS A Multicultural Society 1 (454 Annals, M. Gordon ed. 1981).
} 
before the Civil War, and the late 19th and early 20th centuries. Finally, it will suggest some of the implications of this history for immigration policy today.

Despite the familiar image of the Statue of Liberty holding out a torch of welcome to the poor and oppressed, the history of American immigration policy has been marked by ambivalence toward the admission of newcomers. Throughout that history, immigration advocates and opponents alike have based their positions on both real and imagined characteristics of particular immigrant groups-and on both real and imagined characteristics of the United States at the times when the immigrants have sought admission. Immigration policy, therefore, has reflected the hopes, fears, and needs of the policymakers as much as those of the would-be or actual immigrants.

The Basic Arguments: Pro and Con

Although immigrants have come from widely varying backgrounds and have entered the country at every stage of its territorial and economic growth, the arguments used to support or oppose their admission have remained remarkably consistent from the colonial period to the present day. For instance, proponents of a liberal immigration policy have argued that special categories of people-refugees-should be admitted because they have been victims of political or religious oppression or, less frequently, of natural disaster. Refugees have been perceived as innocent victims of unfortunate circumstances, or as heroic figures demonstrating their appreciation for the American system by choosing it over those of their homelands. Immigrants admitted under these rationales have included Protestant refugees from the wars of the French King Louis XIV, white plantation owners fleeing slave revolts in Haiti, liberal " 48 'ers" escaping repressive regimes after the failure of the European revolutions of 1848 , and, more recently, refugees from Communist-controlled countries in Eastern Europe and Southeast Asia.

Although humanitarianism cannot be discounted as a policymaking motive, not all support for refugees has been disinterested. Immigration has often been championed by groups who found it consistent with a pre-existing political or ideological agenda. Southern slaveholders hurried to assist their displaced counterparts from Haiti because they themselves lived in constant fear of rebellion among their own slaves. Mid-19th century liberals who welcomed the " 48 'ers" sought and often received the newcomers' help in reform movements such as abolitionism and women's rights. Government assistance to the early refugees from Fidel Castro's Cuba was motivated at least in part by their political usefulness in the Cold War and their potential military usefulness against the Castro regime.

Most immigrants, however, have not been refugees. They have been farmers, workers, tradespeople, or, especially in recent years, professionals, immigrating in search of economic opportunity. Advocates of a liberal immigration policy have argued that, since America has always been a nation of immigrants, newcomers should be given the opportunities extended to earlier generations. Minorities have often championed newcomers of similar ethnic or religious backgrounds. From the 17 th century to the 20 th, defenders of a liberal immigration policy have stressed 
the link between immigration and economic development. They have argued that immigrants in search of opportunity are unusually able, energetic, and ambitious, and therefore will be assets to the American economy. Advocates have also argued that immigrants are a cultural asset, enriching American life through their diversity-though few have taken the position that this diversity should be deliberately preserved.

The traditional argument for a generous and open immigration policy has rested on certain assumptions about the immigrants themselves: that they are worthy, productive, and socially desirable, that they will easily adapt to American life, and that their impact upon our society will be minimal and favorable. This argument has also rested on certain assumptions about the United States: that it should be a haven for the oppressed, that it has room and resources for additional people, and that it is strong enough to absorb large numbers of foreigners without endangering its own society and institutions. Restrictionists have not shared these assumptions.

Advocates of a restrictive immigration policy have argued that immigration endangers the nation's economic, political, and cultural welfare. From the Puritans of colonial New England who objected to sharing food with Scotch-Irish newcomers, to taxpayers in Texas who now object to educating the children of illegal Mexican aliens, restrictionists have worried that immigrants would use resources needed by American citizens. Despite its often-expressed ideal of worker solidarity, the American labor movement has often opposed immigration on the grounds that immigrant labor takes American jobs and depresses American wages. $^{2}$

Restrictionists have also argued that, because of their ignorance of the American political system, their ethnic or religious backgrounds, or their ideological affiliations, immigrants constitute a threat to the nation's political institutions. From the 17th and 18th century protests against the arrival of British felons to more recent protests against the arrival of former inmates of Cuban jails, opponents of immigration have warned of immigrant criminality. More importantly, restrictionists have argued that massive infusions of alien beliefs, customs, and genes would undermine the nation's unity, destroy its cultural identity, and mongrelize its population. Unlike their opponents, restrictionists have assumed that immigrants are by definition the worst rather than the best of their nation, and that they can assimilate only with great difficulty, if at all. Restrictionists have assumed that the United States is limited in resources, unable to support additional population, and vulnerable to subversion and corruption by outsiders who would change it before it changed them.

2. See J. Higham, Strangers in the Land: PatTerns of AMErican Nativism 1860-1925, at 7072, 305-06 (1955); see also E. Hutchinson, Legislative History Of AMERICAN IMMIGRATION POLICY $1798-1965$, at $493-94(1981)$. 


\section{'The Arguments Applied: Three Immigration Policy Debates}

The opposing arguments outlined above have been voiced in varying fashions throughout American history. The three case studies that follow will demonstrate how the arguments were expressed in specific policy debates and embodied in America's immigration policy. In the first two instances, taken from the mid-18th and the 19th centuries, respectively, efforts to change a pre-existing open immigration policy failed. In the third case, that of the early 20 th century, the open policy was drastically changed. A numerical limit was placed on immigration from outside the western hemisphere and a quota system was established that discriminated in the admission of individuals on the basis of racial and ethnic background.

\section{A. The Colonial Debate: 1720-1776}

Despite the presence of Native Americans, blacks, Dutchmen, and others, inhabitants of the Thirteen Colonies were predominantly English at the beginning of the 18th century. In the decades that followed, the immigration of hundreds of thousands of Germans and Scotch-Irish led to the first major debate on immigration policy. The Germans, victims of religious and political oppression and of the devastation of many wars, came from the Rhineland. ${ }^{3}$ The Scotch-Irish were Scots who had settled in Ireland but departed because of religious restrictions (as Presbyterians they were dissenters from the established Church of England), and because of a rapid rise in rents. ${ }^{4}$ The Germans settled mostly in the middle Colonies, constituting over a third of the population of Pennsylvania by mid-century, while the Scotch-Irish were more widely distributed and often found their way to the frontier.

The British government and its representatives in the Colonies advocated the admission of virtually all Protestant immigrants. Since the founding of the Colonies, British authorities had encouraged immigration because they needed a labor force to produce wealth and consumers to provide a market for exports from the mother country. With this in mind, the British government granted easy naturalization to non-English immigrants and provided pardons and free transportation to the Colonies for criminals and debtors. Motivated by a desire to provide refuge for persecuted co-religionists as well as to populate his colony, William Penn traveled to Germany to recruit settlers for Pennsylvania. For similar reasons Queen Anne (and later King George) encouraged and financed the emigration of German Protestants. ${ }^{5}$ Emigration was also promoted by private parties, ship captains, and agents who made handsome profits from the traffic in imported indentured servants. ${ }^{6}$

Recognizing the economic value of greater population, colonial governors and

3. See generally W. Beidelman, The Story of the Pennsylvania Germans (1898); A. Faust, The German Element in the United States (1927).

4. See generally H. Ford, The Scotch-Irish in America (1915); J. Leyburn, The Scotch-IRISh: A SOCIAL History (1962).

5. E. Proper, Colonial Immigration Laws 1, 47 (Stud. Hist. Econ. \& Pub. L. No. 12, 1967).

6. W. BeidelmaN, supra note 3, at 43-44. 
legislative assemblies competed to attract immigrants, offering inducements such as cash bounties, free land, tax exemptions, and at least limited religious toleration.7 All Christians-except Catholics-were acceptable. In 1738 the Lieutenant Governor of Pennsylvania asked for an appropriation to build a hospital for German immigrants. If German immigration were slowed or halted, he warned the legislators, "the value of your lands will fall and your advances to wealth be much slower, for it is not altogether the goodness of the soil, but the number and industry of the people that make a flourishing country." 8

The ambivalence of colonial settlers, as opposed to royal officials, toward nonEnglish immigration is suggested by the initial refusal by the Pennsylvania assembly to provide the proposed hospital. The assembly rejected the Lieutenant Governor's equation of German immigration with prosperity, attributing the progress of the colony "chiefly to the lenity of our government, and to the sobriety and industry of the first settlers of this country and the other British subjects inhabiting the same."

Opponents of unrestricted German and Scotch-Irish immigration raised essentially the same economic, political, and cultural arguments that were to become the staples of the restrictionists' case in the centuries that followed. In the preindustrial colonial economy, however, the economic arguments centered on the scarcity of resources rather than on wage competition. In 1718 Bostonians blamed Scotch-Irish immigrants for the shortage of food in the colony and for the rising cost of grain. In 1729 Boston mobs prevented the landing of ships from Ireland for the same reason. ${ }^{10}$

As memories of "starving times" faded and resources became more plentiful, economic arguments became secondary to political and cultural ones. Colonists worried that German immigrants did not understand English government and would therefore undermine it; that being unaccustomed to freedom they would abuse it; and that because they "live in a Body together, as if in a Principality of Germany," they would throw off their loyalty to the British crown or, in case of war, side with Britian's traditional enemy, France. ${ }^{11}$ The last fear was fed in Pennsylvania by the Germans' refusal to vote funds for a strong militia to protect the colony against the French and the Indians, a project most Germans considered a threat to their sons and their pocketbooks. ${ }^{12}$ In 1744 the Governor of New York ordered the colony's Moravians, a German Protestant sect, to dissolve their missions to the Indians, mistakenly believing the missionaries to be Catholic priests and French agents - and therefore doubly enemies of the state. ${ }^{13}$

Arguments against the immigration of Germans stressed their supposed stu-

7. E. Proper, supra note 5, at 11-17.

8. Id. at 51 .

9. Id. (emphasis added).

10. T. Curran, Xenophobia and Immigration 1820-1930, at 13 (1975).

11. K. Wust, The Virginia Germans 52 (1969) (quoting colonial Virginia Governor Dinwiddie from 1 The Orficial Records of Robert Dinwiddie 213 (Brock ed. 1884)).

12. Weaver, Benjamin Franklin and the Pennsyluania Germans, in The Aliens: A History of EThNiC MiNORITIES IN AMERICA 49-51 (1970).

13. Id. at 54 . 
pidity, clannishness, and dubious assimilability. "I really think they [seem] to be as ignorant a Set of People as the Indians. [T] hey would never speak English but when spoken to they speak all Dutch," complained George Washington in $1738 .{ }^{14}$ Benjamin Franklin concurred, "Those who come here are generally the most stupid of their own nation."15 Franklin was also explicit about his fears of cultural inundation:

[W] hy should the Palatine Boors be suffered to swarm into our Settlements and, by herding together, establish their Language and Manners, to the Exclusion of ours? Why should Pennsylvania, founded by the English, become a Colony of Aliens, who will shortly be so numerous as to Germanize us instead of our Anglifying them . . . 16

Opposition to the admission of the Scotch-Irish centered on their poverty and their supposed tendencies toward disorder and violence. Protests against the immigration of felons of any ethnic background were common. "Our Mother [Britain] knows what is best for us," noted a colonial newspaper sarcastically:

What is a little Housebreaking, Shoplifting, or Highway Robbing; what is a Son now and then corrupted and hang'd, a Daughter debauch'd and pox'd, a Wife stabb'd, a Husband's Throat cut, or a Child's Brains beat out with an Axe, compar'd with this "IMPROVEMENT and WELL PEOPLING of the Colonies." 17

The restrictionist arguments reflected realities about colonial life, although not necessarily about the Germans or Scotch-Irish. Localized food shortages did occur and could have been aggravated in the short run by the arrival of impoverished immigrants. The Indians and the French on the frontier posed a genuine danger, as the French and Indian War would soon demonstrate. Many of the Germans did avoid political involvement and officeholding, as well as taxation for a militia, due to their prior experiences with authorities in the homeland or their religious beliefs. By the end of the French and Indian War in 1763, however, the German community was contributing its share to the common defense.

The characterization of Germans as "stupid" was no more than an expression of English colonial ethnocentrism. Franklin and others who held this prejudice could have observed much evidence to the contrary; indeed, Franklin himself commented on the number of German books and printing houses in Pennsylvania. ${ }^{18}$ Fear of a permanent German subculture was more justifiable, since German had in fact become an unofficial second language in Pennsylvania. Franklin could not have known that by the end of the century, the Germans (with the exception of the most conservative religious sects) would be speaking English and integrating themselves into the commercial and social life of the English community. Fears of Scotch-Irish violence also proved unfounded. As the Scotch-Irish gained social status and affluence they became as "respectable" as the English-from whom they were soon virtually indistinguishable. ${ }^{19}$

14. K. WUST, supra note 11 , at 51-52.

15. W. Beidelman, supra note 3, at 85 (quoting Franklin's letter to English botanist Peter Collinson in 1753).

16. 3 Writings of Benjamin Franklin 72 (A. Smyth ed. 1907).

17. Pennsylvania Gazette (B. Franklin ed.), May 9, 1751, at 2, col. 1.

18. W. BeIDELMAN, supra note 3 , at 86 .

19. See J. Leyburn, The Scotch-Irish: A Social History 317 (1962). 
In sum, the English colonists in a new and insecure frontier society had justifiable fears: fear of the French-traditional rivals on their borders; fear of the Indians-whose lands they were seizing; and fear that the wilderness would radically change the way of life they had laboriously brought from England. These problems, however, would have existed with or without the Germans and the Scotch-Irish-at whose doorstep colonial difficulties were all too often simplistically laid.

The ability of the colonists to translate their fears into restrictionist legislation was limited by the structure of colonial government. Most colonial assemblies had to contend with royal governors, and all were subject to the authority of the Crown and Parliament. Unable to stop foreign immigration directly, colonial assemblies tried to discourage it through indirect means; they enacted special taxes, land restrictions, and religion-based voting qualifications to discourage the immigration of Catholics. ${ }^{20}$ British authorities upheld this legislation; Catholicism was only reluctantly tolerated in England and the national enemies-France and Spain-were Catholic. Nevertheless, colonial efforts to reduce the immigration of the Germans and the Scotch-Irish, by levying a head tax on each immigrant, or by requiring ship captains to post bond for all passengers, were not successful. In Pennsylvania, where the English majority would probably have stopped German immigration if possible, ${ }^{21}$ royal governors vetoed restrictive taxes on several occasions. ${ }^{22}$ Moreover, Pennsylvania's German community was so large and wellorganized by mid-century that it was able not only to help block restrictions, ${ }^{23}$ but also to secure legislation protecting the health, safety, and legal rights of immigrants during passage. ${ }^{24}$

Ironically, by the time of the American Revolution the British authorities and the colonists had reversed their positions on immigration. After 1763, British authorities began to limit immigration because settlement of the West made the colonies harder to defend. In 1774, Parliament cut off immigration to the colonies entirely. ${ }^{25}$ The colonists, on the other hand, were by now so thoroughly convinced that immigration meant growth and prosperity that the British domestic policy of restricting emigration was listed in the Declaration of Independence as one of the reasons for breaking political ties with the mother country. Political leaders still occasionally expressed concern about the political reliability of immigrants ${ }^{26}$ and declared the need for their assimilation into English colonial culture. Nevertheless, the United States began its career as an independent nation with a totally open

20. T. CURRAN, supta note 10 , at 12-13.

21. PROPER, supra note 5 , at 52 .

22. Id. at 53.

23. Id. at $52-53$.

In 1755, the Governor of Pennsylvania vetoed "An act for preventing the importation of Germans or other passengers in too great numbers in any ship," arguing that it amounted to an absolute prohibition of Germans "which might not look well at home nor be for the interest of the province." Id. at 53.

24. A. Faust, The German Element in the United States 71.72 (1927).

25. See T. Curran, supra note 10 , at 14 .

26. Quotations to this effect from the writings of George Washington, John Adams, Patrick Henry, Thomas Jefferson, Alexander Hamilton, and other Founding Fathers have been cited in many restrictionist works. For a representative selection, see The ALIEN in OUR MIDST, OR "SElliNG OUR BiRTHRIGHT FOR a Mess of Industrial Pottage” (M. Grant \& C. Davison eds. 2d ed. 1930). 
immigration policy. There were no qualitative restrictions. The waiting period for naturalization was only two years ${ }^{27}$ (changed to five years in 1795). ${ }^{28}$ The Constitution denied no national office except the Presidency to the foreign born.

\section{B. Antebellum Nativism: 1830-1860}

Half a century later, this open-door policy was vociferously, albeit unsuccessfully, challenged. By the mid-1850's, members of nativist organizations were pledging never to support a "foreigner" for public office. A national political party was electing Congressmen who advocated a twenty-one year waiting period for naturalization. Some restrictionists were suggesting that the gates be closed altogether.

Like its colonial predecessor, the antebellum debate was touched off by a sudden increase in the number of immigrants. The 1820's saw 150,000 immigrants enter the country, a number which quadrupled in the 1830 's, rose to more than $1,500,000$ in the 1840's, and peaked at nearly 2,500,000 in the 1850's. On the eve of the Civil War, one out of every seven Americans was either an immigrant or the child of an immigrant. ${ }^{29}$ Most of these newcomers were Irish Catholics, Germans (many of them also Catholic), Scandinavians, and Chinese-people whose religion, language, or ethnic background differed from the white Anglo-Saxon Protestant American norm. The intensified public debate was a response to these differences as well as to the increasing numbers of new immigrants. It also expressed the deeper tensions of a nation undergoing many rapid changes simultaneously: expansion, urbanization, industrialization, reform, and the sectional conflict that would soon erupt in civil war.

Some of the immigrants were refugees from political upheavals-the Polish immigrants of 1830, for example, and the famous German "48'ers." More were fugitives from the potato famine that blighted Ireland and areas of northern Europe. Most, however, were land-hungry farmers or displaced laborers, craftsmen, or petty tradesmen seeking better economic opportunities for themselves and their children. ${ }^{30}$

Support for an open immigration policy was strong, though not always vocal. Many Americans sympathized with the refugees and famine victims, and saw their coming as confirmation of the widespread conviction that the United States was in every way superior to Old World countries. With cities doubling their size every decade and a seemingly limitless expanse of western land to settle, immigrants were welcomed as a source of labor. Like the Colonies a century earlier, southern and western states actively recruited immigrants; greater population increased their representation in Congress, swelled tax receipts, introduced skills, and increased land values. ${ }^{31}$ Business interests also supported and encouraged immigration. Railroads were especially active in recruitment; in addition to laying the

27. Act of Mar. 26, 1790 (1 Stat. 103).

28. Act of Jan. 29, 1795 (1 Stat. 414).

29. A. TYler, Freedom's Ferment 375 (1944).

30. See L. Dinnerstein \& D. Reimers, supta note 1, at 12-16; M. Seller, supta note 1, at 58-64.

31. M. SELLER, supra note 1 , at 64-66. 
rails, immigrants bought land from the railroads, paid fares to reach the new territories, and then used the railroads to bring in supplies and to market their crops.

Restrictionists revived colonial protests that immigrants used up scarce resources in their complaints that immigrants inordinately relied upon charitable institutions and drained the nation of capital by sending money to their relatives overseas. The beginnings of urbanization and industrialization, however, shifted the focus of the economic argument to wage and job competition ${ }^{32}$ and to issues of class conflict. An 1856 publication, Immigration: Its Evils and Consequences, warned that "by depreciating the value of American labor" immigrants increased the power of American and British capitalists, who "rule the money market of the world." 33 In 1852 a group of white miners in California, worried about Chinese competition, adopted a resolution denouncing the "capitalists, shipowners, and merchants" who encouraged Chinese immigration and urging that "no Asiatic or South Sea Islander be permitted to mine in this district . . . ."34

While economically motivated protests usually peaked during periodic recessions or "panics," politically and religiously motivated protests were more sustained. Americans were self-consciously proud of their unique political system, and worried that immigrants would undermine it through ignorance, corruption, or even conspiracy. Uncertain as yet of the consequences of universal white male suffrage, the "better," propertied classes worried that radical 48 'ers would lead the nation to socialism and anarchy and that vote selling among the new Irish voters in the cities would result in a hopelessly corrupt urban government-and in the defeat of the Whigs by the Irish-supported Democrats.

The most widespread political fear, however, was of subversion through Roman Catholicism, the religion of half the German and virtually all the Irish immigrants. Catholicism was associated in the minds of many Protestant Americans with France and Spain, traditional enemies of the British and their dependencies during the colonial period and suppressors of liberal revolutions in Europe and Latin America in the 19th century. At a time when militant Protestantism was the bastion of militant Americanism, Catholic leaders here and in Europe announced their intention to proselytize in the United States. Even as militant Americans were hailing their newly established public schools as the bulwark of the republic, Bishop John Hughes of New York led a campaign to raise public money for Catholic schools. ${ }^{35}$ Lurid anti-Catholic literature flooded the nation and became an important component of the demand for a change in immigration policy. Inventor Samuel F.B. Morse warned that immigrants were agents of the Pope, who had sent them to prepare for a Catholic takeover of the United States. "Will you be longer deceived by the pensioned Jesuits . . . ? Fly to protect the vulnerable places of your Constitution and Laws. Place your guards; you will need them,

32. A. Tyler, supra note 29, at 376, 386; see also R. Billington, The Protestant Crusade 18001860: A Study Of THE Origins Of AMERICAN Nativism 334 (1964).

33. S. Busey, Immigration: Its Evils and Consequences 82, 81 (2d ed. 1969)(1st ed. New York 1856).

34. A. Mcleod, Pigtails and Gold Dust 67 (1947)

35. D. Ravitch, The Great School Wars 46-57 (1974); see also Lannie, Catholics, Protestants, and Public Education, in CATHOLICISM IN AMERICA 52 (P. Gleason ed. 1970). 
and quickly, too. And first, shut your gates."36

Advocates of immigration restriction produced documents which indicated that foreign governments were "dumping" criminals and paupers in the United States. These restrictionists assembled figures on the number of immigrants in urban prisons, insane asylums, and poorhouses-all proof that these were the worst their homelands had to offer. ${ }^{37}$ Evangelists and moral reformers viewed immigration as an obstacle to their crusade for a pure, clean, sober, Sabbath-observing, Protestant America. The Chinese were denounced as treacherous, licentious heathens addicted to opium, infanticide, gangsterism, and filth. ${ }^{38}$ The Irish were only slightly less vilified: "[S]o filthy and ignorant a mass of humanity we have never seen on the face of the earth," wrote one hostile observer. 39 Another asked, "Can one throw mud into pure water and not disturb its clearness?"40 The dismal living conditions in the new urban slums offered further "proof" of immigrant depravity. ${ }^{41}$

In retrospect, most of these restrictionist arguments appear to have been based on misconceptions. There were periods of localized unemployment, particularly in northeastern cities where unskilled, American-born labor competed with immigrants. Unemployment among skilled workers, however, reflected technological change and the fluctuations of a rapidly changing economy more than it did the presence of immigrants. Despite periodic "panics," real wages did not decline during the decades before the Civil War, the economy expanded, and native-born workers could rise to better-paying positions, leaving the work they did not want to the incoming immigrants. ${ }^{42}$

Restrictionists were correct in arguing that foreign governments were sending criminals and paupers to the United States, ${ }^{43}$ but tended to exaggerate their numbers and impact. Nativists were also correct in noting the widespread dependency of immigrants in the East upon public charity, ${ }^{44}$ but incorrect in attributing this to depravity rather than to poverty. Crime, prostitution, drunkenness, and Sabbathbreaking predated the coming of the immigrants, as did urban political corruption; the reformers' crusades were thwarted by the native-born as well as by the foreigner.

As one historian has noted, "[f]undamentally the aliens were opposed because they were Catholics rather than because they were paupers or criminals."45 Much of the apprehension about immigration reflected Protestant distress at the dramatic growth of American Catholicism. The Catholic population increased from

36. S.F.B. MORSE, ImMinent DANGers TO THE Free Institutions OF THE United States Through Foreign IMMIGRATION 25 (New York 1835) (published under pseudonym "An American").

37. S. BUSEY, supra note 33 , at $66-76$.

38. S. Miller, The Unwelcome Immigrant: The American Image of the Chinese 68 (1969).

39. N.Y. Am. Republican, July 8, 1844, at 2, quoted in T. CuRRAN, supra note 10, at 36.

40. S.F.B. MORSE, supra note 36 , at iv.

41. For a vivid description of these conditions, see R. Ernst, ImMIGRANT Life in New York City 1825-1863 (1949).

42. See R. Billington, supra note 32 , at 334-35.

43. See id. at $34-36,134$.

44. Id. at 324 .

45. Id. at 36 . 
about 75,000 (or $1 \%$ of the nation) in 1810 , to $3,000,000$ (or $10 \%$ ) in 1860.46

Poverty, not the Papacy, sent Irish Catholics to the United States. The old world Catholic monarchies-reactionary as they may have been-were scarcely able to maintain order in Europe, much less present a credible threat to the United States. Neither the public school system nor Protestantism was in jeopardy. The anti-Irish, anti-Catholic hysteria must be attributed to demagoguery, to inherited prejudices, and to a young nation's need to confirm its identity as a Protestant, Anglo-Saxon republic by perceiving "threats" posed by monarchical, Catholic enemies at home as well as abroad.

The decades from 1830 to 1860 were marked by frequent rioting between immigrant Democrats and native-born Whigs at election time and by occasional attacks on Catholic immigrants and institutions. An Ursaline convent and school in Massachusetts were burned in $1834 .{ }^{47}$ Several people were killed and many more were wounded during street fighting in Philadelphia ten years later. ${ }^{48}$ Dozens of nativist "patriotic" societies were formed and in the early 1850's a national political party, the American (or "Know-Nothing") Party emerged. In 1854, this nativist party carried Massachusetts and Delaware and sent seventy-five Congressmen to Washington- "pledged to carry the nation into a war against the Pope and his minions."49 A year later the American Party gained control of Rhode Island, New Hampshire, Connecticut, Maryland, and Kentucky and made substantial gains in New York, Pennsylvania, and California. ${ }^{50}$

Surprisingly, none of this activity resulted in any change in the nation's liberal immigration policy. Congressional efforts to discourage immigration by increasing the naturalization period to twenty-one years failed, ${ }^{51}$ as did efforts to forbid the immigration of illiterates, criminals, and paupers. ${ }^{52}$ Many Congressmen who favored immigration restriction did not vote for it, fearing that the enlargement of the limited powers of the Federal Government in this area might set a precedent for federal legislation against slavery. At the state level, action was directed to fruitless investigations of convents and, in Massachusetts, to short-lived constitutional amendments which confined officeholding to the native-born and limited the vote to persons residing in the country for at least twenty-one years. ${ }^{53}$ The early electoral victories of the American Party were not repeated after 1856, and by 1860 the party was dead, along with its restrictionist agenda. ${ }^{54}$

Excessive zeal and internal corruption had weakened the party, but its defeat was accelerated by other factors. The party had been strongest in New Englandwhere Irish immigrants were numerous and the disruptions of early industrialization most strongly felt - and in border states-where moderates were looking for

\footnotetext{
46. A. TYLER, supra note 29 , at 361 .

47. Id. at $370-71$.

48. Id. at $380-81$.

49. T. CURRAN, supra note 10 , at 338 .

50. Id.

51. R. Billington, supra note 32 , at 410-11.

52. Id. at 411-12.

53. Id. at 413. These Massachusetts constitutional amendments were soon repealed by a later state legislature. Id.

54. Id. at 430 .
} 
an alternative to national parties polarized over the issue of slavery. Restrictionism held little appeal for voters in the West, where immigration meant growth and prosperity.

Neither the Federal Government nor the states had been inclined to limit immigration in the 1830's and 1840's, because these were decades of territorial and economic expansion. The era of biological racism had not yet arrived. Most people were optimistic about America's future and confident that unlimited num. bers of immigrants (with the possible exception of the Chinese) could be assimilated by means of the frontier, the public school, and other obviously superior American conditions and institutions. In the 1850's, the controversy over slavery in the territories increasingly dominated all other issues. The American Party, the last antebellum movement to focus on an issue that was national rather than sectional, could not succeed. As the decade progressed the party, like the rest of the country, divided along sectional lines. The real issue facing the country was slavery, not immigration.

\section{Toward the National Origins Quota: 1882-1924}

A dramatic change in the nation's previously open immigration policy began in 1882 with the exclusion of most Chinese immigrants ${ }^{55}$ and culminated in 1924 with the exclusion of all Asian and African immigrants and the sharp limitation of southern and eastern Europeans. ${ }^{56}$ Advocates of the new policy attributed its adoption to changes in the quality of immigration. Historians have found, however, that in motivation, skills, and adjustment problems, the "new" immigrants differed little from earlier arrivals. The country that received them was different, however. No longer a relatively isolated rural society, the United States was emerging as a world power, an industrial giant, and a nation of cities. Ironically, these changes were accompanied by a loss of the self-confidence and optimism that had supported the policy of unrestricted immigration.

As had been the case in the antebellum period, the turn of the century debate about immigration policy was precipitated by a sharp increase in the number of immigrants. Total immigration in the three decades preceding the Civil War had numbered 5,000,000. Between 1860 and 1890 that number doubled, and from 1890 to 1914 it tripled, with over $1,000,000$ entering annually in 1905, 1906, 1907, 1910,1913 , and $1914 .{ }^{57}$ By 1920 almost $60 \%$ of the population of cities of over 100,000 consisted of the foreign-born or their children. ${ }^{58}$ While most antebellum immigrants had been from northern and western Europe, by 1907 80\% had emigrated from southern and eastern Europe. ${ }^{59}$ Early 20th century immigration included large numbers of Italians, Jews, Poles, and other Slavs, and smaller numbers from Japan, Mexico, Canada, and the West Indies. ${ }^{60}$

55. Chinese Exclusion Act of 1882, ch. 126, 22 Stat. 58 (repealed 1943).

56. Act of May 26, 1924, ch. 190, 43 Stat. 153 (repealed 1952).

57. M. SELLER, supra note 1, at 104-05.

58. D. WARD, CitIES AND IMMIGRANTS 52 (1971).

59. M. SELLER, supra note 1 , at 105.

60. See L. Dinnerstein \& D. Reimers, supra note 1 , at 36-39, 162-65. 
The forces that favored a continuation of open immigration were varied and, until after World War I, strong enough to prevent a decisive change in immigration policy toward Europeans, if not toward Asians. Prior to the war, humanitarian motives remained important; many Americans were sympathetic to the plight of Jews fleeing savage pogroms in Russia and Armenians escaping massacres in Turkey. Among intellectuals and social workers there was sincere, if sometimes condescending, support on the ground that ethnic neighborhoods were colorful and quaint or, more substantially, that immigrant cultures enriched American life. ${ }^{61}$ Home missionaries in the new metropolitan centers favored continued immigration as an opportunity to win souls for Protestantism. ${ }^{62}$ At times Catholic leadership, reflecting the heavy immigrant composition of the Church, expressed unofficial opposition to efforts to restrict immigration. ${ }^{63}$ Politicians in ethnic districts vied with one another in expressing support for continued immigration, as did the Republican, Democratic, and Progressive parties in the presidential election of 1912.64 More importantly and more consistently, the immigrant communities themselves sought to keep the doors of immigration open. Organizations such as the Polish National Alliance, the German-American Alliance, and the American Jewish Committee held mass meetings, circulated petitions, and sent delegates to Congressional hearings on immigration policy. ${ }^{65}$

The most influential group to support continued open immigration during most of this period was American business. A second-rate industrial power at midcentury, the United States was by 1890 the world's leading industrial power. Its manufactured goods were almost equal in value to those of England, France, and Germany combined; its railroad mileage was greater than that of all Europe, including Russia. Except in the South, immigrants formed the largest segment of the labor force for this unprecedented expansion. ${ }^{66}$ Immigration guaranteed an ample and inexpensive supply of unskilled and semi-skilled labor, and enabled industrialists to thwart efforts at unionization by pitting immigrant against nativeborn or one ethnic group against another. As late as 1921 , the southwestern cotton growers, the Colorado beet producers, the National Federation of Construction Industries, and the National Association of Manufacturers all opposed the institution of restrictive quotas. ${ }^{67}$

Ironically, the enormous industrial expansion that was fueled in part by immigrant energies contributed significantly to the imposition of restrictions. Unprecedented growth was punctuated by unprecedented panics, and by a sustained major depression in the 1890's in which perhaps one-fifth of the workforce was unemployed. Strikes to protest the lowering of wages were violently suppressed.

61. Among those who wrote sympathetically and at times even romantically about ethnic ghettos were journalists Hutchins Hapgood and Lincoln Steffens, novelist William Dean Howells, and social worker Robert Woods, who organized the National Foundation of Settlements.

62. See Seller, Protestant Evangelism and the Italian Immigrant Woman 1890-1920, in ThE ITALIAN IMMIGRANT WOMAN IN NORTH AMERICA 124 (B. Caroli ed. 1978).

63. See J. HighaM, supra note 2 , at 188 .

64. Id. at 189 .

65. Id. at 188 .

66. J. Blum, The National Experience: A History or the United States 437-38, 456 (1968).

67. J. Higham, supra note 2, at 310 . 
The ever increasing concentration of wealth and power in the hands of giant corporations, along with the announcement in 1890 that the frontier was officially closed, made many ordinary Americans feel, for the first time, that their opportunities for the pursuit of wealth were limited and that therefore America had no room for further newcomers. ${ }^{68}$

Not surprisingly, American labor-including many of the foreign-born-protested that immigrants were taking American jobs, serving as strikebreakers, and working for wages unacceptable to American labor. Irish-born Dennis Kearney, a founder and board member of the Workingman's Trade and Labor Union of San Francisco, led the fight to halt Chinese immigration in the aftermath of the depression of 1877.69 In the 1880's, the Knights of Labor urged a ban on the importation of contract labor. ${ }^{70}$ The newly organized American Federation of Labor vacillated in the 1890's, but moved solidly into the restrictionist camp by $1907.7^{11}$

Although an organization called the American Protective Association revived antebellum arguments that Catholic immigrants endangered the public schools and the republic, ${ }^{72}$ anti-Catholicism had lost much of its emotional power. Not to be deprived of their appeals to religious fanaticism, restrictionists could also invoke anti-Semitism. Beleaguered farmers and workers blamed their economic distress on international monied interests symbolized by Jews; the respectable middle class reviled Jewish "aggressiveness." In the 1920's, Henry Ford of automotive fame warned, through a magazine available at his auto dealerships, of an international Jewish conspiracy. ${ }^{73}$

Economically based arguments against immigration had largely subsided with the return of prosperity at the end of the century, but political fears increased as World War I approached. Even before the United States entered the war, attempts on the part of the German-American community to influence the nation's pro-British foreign policy aroused a storm of protest. About one-third of all the foreign born in the United States were from Germany, the Austro-Hungarian Empire, or Turkey. Once the United States entered the war, these immigrants became "enemy aliens" and potential saboteurs. "Reckon each as a pound of dynamite - surely a modest comparison," wrote Samuel Hopkins Adams. "Not all these enemy aliens are hostile. Not all dynamite explodes."74

The jingoistic atmosphere of World War I led to a campaign against "hyphenation" and for "100 percent Americanism." This focused attention on the fact that many immigrants lived in ethnic communities, maintained a lifestyle different from mainstream America and, especially in the immediate postwar peiod, lobbied actively for a peace settlement favorable to their native lands. The perceived

68. See T. Curran, supra note 10, at 93; M. SELler, supra note 1, at 199.

69. T. CURRAN, supra note 10 , at 84 .

70. J. HighaM, supra note 2 , at 48 .

71. Id. at 71-72, 163.

72. J. HighaM, supra note 2, at 80-87.

73. Id. at 282-83.

74. Adams, Invaded America, Everybody's Magazine, March 1918, at 55-56, quoted in J. HighaM, supra note 2, at 214 . 
failure of crash campaigns to "Americanize" these millions led many to conclude in the early 1920's that immigration policy should be radically altered.

Fear of immigrant radicalism had erupted much earlier with the Haymarket bombing in 1886 and had run through the strikes and labor unrest of the depression decade that followed. It gained momentum when socialists, many of them foreign born, opposed America's participation in World War I, and it reached a peak during the Red Scare, the strikes, and the recession of the immediate postwar years. In the Palmer Raids of 1919 and 1920, thousands of aliens-mostly Jews, Italians, and Slavs-were arrested and deported as anarchist or Bolshevik revolutionaries, often on the flimsiest of evidence. ${ }^{75}$ The stereotyping of southern and eastern Europeans as radicals was a major factor in the greater restrictionist victory that was to come. ${ }^{76}$

The familiar cultural and moral arguments concerning immigrant filth, crime, sin, and political corruption reappeared. Like the reformers of the antebellum generation, 20th century progressives turned to restriction as a tool in their campaigns for urban reform and Prohibition.

Arguments that immigrants caused cultural or moral contamination were old; arguments that they caused racial contamination were new, a product of the scientific age. By the late 19th century, widespread acceptance of the germ theory had led to concern that immigrants were a menace to public health. Restrictionists warned Congress that importation of Chinese labor into California introduced "frightful and nameless [sic] diseases and contagions" such as "Asian" cholera, "Chinese" syphilis, and leprosy. ${ }^{77}$ Throughout the nation, foreign-born servants were suspected of infecting the households of the comfortable.

Although the faults of earlier immigrant groups had been attributed to their environment and had thus been thought correctable, the new physical and social sciences emphasized the hereditary (and therefore immutable) nature of the same defects. Anthropologists, psychologists, physicians, and others demonstrated "scientifically"-_by measuring skulls and forehead angles to compute cranial capacity - that Slavs and Italians were less intelligent than Scots and Norwegians, and that Asians and blacks were the least intelligent of all. ${ }^{78}$ The inferiority of the "new" immigrants was confirmed by intelligence tests given in the Army during World War I and soon after in the schools, where children of Polish and Italian immigrants tended to score five to fifteen points lower than their mainstream American counterparts. ${ }^{79}$ Educator Clifford Kirkpatrick warned, on the basis of such tests, that recent immigration was lowering the nation's collective intelligence

75. See R. Murray, Red Scare: A Study in National Hysteria 1919-1920, at $210-22$ (1955).

76. See id. at 265.

77. See S. MILler, supra note 38 , at 164-65.

78. See J. HighaM, supra note 2, at 131-57.

79. See C. Kirkpatrick, InTElligence and Immigration 15-35 (Mental Measurement Monograph No. 2, 1926).

Kirkpatrick's monograph collects a variety of contemporary studies which employed varying methodologies (from the Stanford-Binet I.Q. test to more subjective "rates of retardation") in a variety of settings (from the armed forces to the public schools). These studies generally "demonstrated" deficient intelligence on the part of southern and eastern European immigrants and blacks, as compared with "Americans" and immigrants from more Nordic climes. 
and urged a more restrictive, "scientific" immigration policy. Kirkpatrick and others pointed with alarm to the fact that the supposedly inferior groups were reproducing faster than old-stock Americans, thus compounding the gloomy prognosis of national genetic decline. ${ }^{80}$

Time has not vindicated Kirkpatrick and other advocates of theories of genetic inferiority. Recent census studies ${ }^{81}$ indicate that descendants of supposedly inferior Asians and southern and eastern Europeans have achieved educational and income levels at or above the national average. For that matter, even contemporaries of Kirkpatrick were aware of the role played by cultural bias in intelligence testing and of the questionable correlation between cranial capacity and intellectual capacity. ${ }^{82}$

From the perspective of over half a century later, the arguments of restrictionists between 1882 and 1924 seem, like their earlier counterparts, a mixture of halftruth and fantasy. Immigration was clearly an asset rather than a liability to the economy, supporting the expansion of established industries such as steel and mining, and creating new ones such as readymade clothing. Despite periodic unemployment, the era as a whole was characterized, as was the early 19th century, by a labor shortage, not a labor surplus. Native-born labor moved up, not out, as immigrants moved into the heavy, dirty, and unskilled jobs that their predecessors no longer wanted. Moreover, because immigrant labor expanded and contracted with the business cycle (almost $40 \%$ of the immigrants during this period returned to their homelands permanently, and many went back and forth as "birds of passage"), immigrant labor helped to minimize job instability for the native born. ${ }^{83}$

Tales of Jewish or Papal plots were pure fabrication and demagoguery. Perhaps motivated by economic expediency, Henry Ford eventually retracted his anti-Semitic charges. ${ }^{84}$ Fears of immigrant sabotage during World War I were equally unfounded-a byproduct of wartime hysteria. Immigrants served in the armed forces in proportionately greater numbers than their native-born counterparts. ${ }^{85}$ Immigrants did participate in strikes and some-like other Americansresponded to economic inequality by becoming socialists or anarchists. The overwhelming majority, however, wanted to join the capitalist system, not to overthrow it. Finally, although violent strikes and the bomb scares of the postwar years frightened the nation, the radical element was so small and its views so alien

80. Id. at 112, 108-10; see also Clark, Birth Rale and Native Intelligence, 14 PsyChOlOGICAL CliniC 111 17 (1922); Davie, Immigration and the Declining Birthrate, 19 SCI. MONTHLY 68-76 (1924).

81. See Sowell, Race and I.Q. Reconsidered, in EsSAyS AND DATA ON AMERICAN ETHNIC Groups 203-38 (T. Sowell ed. 1978) and Sowell \& Collins, Statistical Data on American Ethnic Groups, in EsSAYS AND DATA ON AMERICAN EThinic Groups 251-415 (T. Sowell ed. 1978).

82. See, e.g., Arlitt, On the Need for Caution in Establishing Race Norms, 5 J. APPLIEd PsYCHOLOGY 179 (1921); Davidson, The Social Significance of the Amy Intelligence Findings, 16 SCI. MONTHLY 184 (1923); Saer, An Inquiny into the Effect of Bilingualism upon the Intelligence of Young Children, J. EXPERIMENTAL PEDAGOGY 266 (1922).

83. For an excellent contemporary critique of the economic argument against immigration, see I. HOURWICH, IMMIGRATION AND LABOR (1912).

84. See J. HighaM, supra note 2 , at 327.

85. Id. at 216 . 
to mainstream thinking that no real danger existed. ${ }^{86}$

Dirt, overcrowding, and other unpleasant conditions did exist in immigrant neighborhoods, to the dismay of the residents as well as their critics; but, contrary to popular belief, crime was lower among immigrants than among the native born. ${ }^{87}$ The physical and social problems prevalent in the living quarters of the "new" immigrants were due to poverty and inadequate urban services rather than to the inferiority of their southern and eastern European inhabitants. Similar problems plagued the neighborhoods of both the native-born poor and immigrant groups of earlier generations.

As the newer immigrants contended with adverse conditions in America, those who would follow them encountered increasing resistance. Restrictionist arguments won increasing support during this period, in spite of their weaknesses. State regulation of immigration, never very effective, was declared unconstitutional in $1876,{ }^{88}$ forcing those who favored a change in immigration policy to turn to Washington. ${ }^{89}$ The decades that followed saw a movement of the Federal Government into immigration regulation roughly contemporary with its movement into the regulation of railroads, corporations, drugs, and alcohol. Immigration restriction is at least partly a product of the Progressive commitment to social engineering.

The first major restrictionist victory was the Chinese Exclusion Act of $1882,{ }^{90}$ which in effect limited immigration from China to a few students and merchants annually. Fueled by longstanding racism, the restrictionist movement in California was brought to a head by severe unemployment in the late 1870's and by the belief of ambitious but frustrated whites that huge corporations using imported Chinese labor were shutting them out of agriculture, mining, and manufacturing. Anti-Chinese prejudice was nationwide: the California Congressmen had political leverage in Washington and the Chinese had none. Consequently, Congress passed the Chinese Exclusion Act (and regularly renewed it ${ }^{91}$ until its repeal during World War II). ${ }^{92}$ In 1907 a "gentleman's agreement"93 sharply limiting Japanese immigration followed in the tradition of Chinese exclusion. ${ }^{94}$

Limitation of white European immigration was more difficult. At the urging of organized labor, contract labor was outlawed in 1885.95 Increasingly strict federal laws were also passed against the admission of idiots, lunatics, paupers, prosti-

86. R. MURRAY, supra note 75 , at 31-32 (1955).

87. G. AbBott, ThE Immigrant AND the Community 111 (1917).

88. Henderson v. Wickham, 92 U.S. 259 (1876).

89. R. Divine, American Immigration Policy 1924-52, at 2 (1957).

90. Ch. 126, 22 Stat. 58 (1882) (repealed 1943).

91. Act of May 5, 1892, ch. 60, 27 Stat. 25; Hawaii Annexation Act of 1898, ch. 55, 30 Stat. 750 (extending prior acts' coverage to would-be Hawaiian emigrants); Act of April 29, 1902, ch. 641, 32 Stat. 176; Act of April 27, 1904, ch. 1630, 33 Stat. 428 (renewing Chinese exclusion once again, but. this time without prospective limitation of the restrictions).

92. Act of December 17, 1943, ch. 344, 57 Stat. 600.

93. See E. HUTCHINSON, supra note 2 , at 431.

94. One historian has recently argued that racist stereotypes have been underestimated and economic motivations exaggerated in standard accounts of the effort to restrict Oriental immigration. S. MILLER, supra note 38 , at 4.

95. See E. Hutchinson, supra note 2 , at 88 . 
tutes, and criminals, ${ }^{96}$ but if restrictionists were to attain their more ambitious goals, regulations affecting whole groups rather than just individuals would be needed. The most widely favored device between 1890 and 1920 was the literacy test. Rational and free of ethnic bias on its face, the test would curtail immigration from southern and eastern, but not western, Europe. ${ }^{97}$

Congress first sought to enact a literacy test in $1896,{ }^{98}$ but the act was vetoed by President Grover Cleveland with support from Southern Congressmen who wanted immigrant labor for the industrialization of their states. ${ }^{99}$ Recommended by the Federal Immigration Commission in 1911,100 the literacy test was again proposed by Congress in 1913, ${ }^{101} 1915,{ }^{102}$ and $1917,{ }^{103}$ only to be vetoed by Presidents Taft and Wilson. ${ }^{104}$ In 1917 Congress enacted the literacy test over President Wilson's veto, ${ }^{105}$ thus reflecting the heightened nationalism and fear of aliens generated by the war.

When the new literacy law did not significantly reduce the number of "undesirable" immigrants, stronger measures were taken. In 1921 Congress imposed a limit on total immigration and established a quota system limiting annual immigration from each European nation to $3 \%$ of the number from that nation residing in the United States as of 1910. ${ }^{106}$ This measure reduced the "new" immigration to $20 \%$ of its 1914 total while leaving the "old" immigration at its prewar level. Southern and eastern European immigration was further reduced in 1924, when the base census year was changed from 1910 to $1890 .{ }^{107}$ The proportion of English immigrants was increased at the expense of all other groups after 1929, when quotas for individual groups were based on their percentage of the entire American population ${ }^{108}$ (although no one was quite sure how to determine just what this was). Asian immigration was prohibited altogether, ${ }^{109}$ but immigration from within the Western Hemisphere was unrestricted.

Advocates of the national origins quota legislation were victorious for many reasons. Postwar strikes, unemployment, and economic depression set the stage, as did the popularization of the new pseudoscientific racism and the Red Scare. The earlier supporters of an open immigration policy fell away. Advocates of the "melting pot" despaired that it was not working. In the postwar recession, eastern business was more afraid of immigrant radicalism than of labor shortages, while western representatives could vote for the measures without jeopardizing their

96. Id. at $405-36$.

97. Id. at 482 .

98. Id. at $116-21$.

99. Id. at 121 .

100. U.S. IMmigRation COMmission, 1 ABSTRACTS OF REPORTS OF THE IMMIGRATION COMMISSION, S. Doc. No. 747, 61 st Cong., 3d Sess. 47 (1911).

101. E. HUTCHINSON, supra note 2, at 154 .

102. Id. at 163

103. Id. at 167 .

104. Id. at 154,163 .

105. Immigration Act of February 5, 1917, ch. 29, 39 Stat. 874 (amended 1952).

106. Act of May 19, 1921, ch. 8, 42 Stat. 5 (amended 1924).

107. Act of May 26, 1924, ch. 190, 43 Stat. 153 (repealed 1952).

108. See E. HUTChINSON, supra note 2, at 212.

109. See id. at 434 . 
supply of cheap Mexican labor which had been exempted. Using the racist arguments of the restrictionists to justify their antiblack policies, Southerners dropped their support of open immigration, while ethnic Americans of northern or western European stock were flattered because the proposed legislation distinguished between themselves and the undesirables from other areas. Meanwhile, a revived $\mathrm{Ku}$ Klux Klan expressed, among other things, the unease of some Americans with Jews and other foreigners.

The passage of the national origins quota legislation can be viewed as the triumph of apprehension over hope. Three decades of domestic reform had not solved the problems of how to live with giant corporations, giant cities, and giant inequalities in wealth and opportunity at home, nor had the crusade to make the world safe for democracy shed any light on how to make foreign countries stable, peaceful, and democratic. The movement to exclude Asian and eastern European immigrants contained an element of scapegoating mixed with nostalgia and discouragement. Consciously or unconsciously, many Americans blamed the "new" immigrants for ruining the secure, moral, and egalitarian America of their rural past, an America that existed mainly in the imagination. Limiting immigration to the old familiar English and northern European Protestant groups was less a response to dangers presented by other immigrants than an attempt to escape frustrating changes at home and abroad by returning to "normalcy."

\section{IV}

\section{IMPLICATIONS FOR THE 1980'S}

The immigration policy debate of the 1980's has arisen out of much the same phenomenon that initiated the three historical policy debates described above-a dramatic rise in immigration by people different from the American mainstream. Like their predecessors in the antebellum decades and at the turn of the century, the newest immigrants are coming to a nation experiencing important economic and political changes. Historical experience suggests that arguments over immigration policy must be examined with an awareness of their relationship to other national agendas.

The numerical increase in immigration in the past decade and a half has been striking. From a low of less than 100,000 annually in the 1930's and early 1940's, immigration climbed to a total of 2,500,000 over the 1960's. In 1978 alone immigration surpassed 600,000 , and it has increased every year thereafter. ${ }^{110}$ If undocumented or illegal immigration is included, the current annual total may be approaching the pre-World War I level of 1,000,000 annually.

Equally striking is the change in the source of the current immigration, most of which now comes from the Third World rather than Europe. European immigration decreased from $1,300,000$ in the 1960 's to 842,000 in the 1970 's while, during the same period, Asian immigration jumped from 362,000 to 1,500,000; African from 33,000 to 87,000; South American from 219,000 to 266,000; and Mexican

110. Reimers, supra note 1 , at 7 . 
from 432,000 to $624,000 .^{111}$ In 1977 the three largest sources of immigration were Mexico, the Philippines, and Korea. ${ }^{112}$

This new wave of immigrants, with its unprecedented number of Asians and Hispanics, entered a nation experiencing an energy crisis, a stagnating economy, an uncontrolled inflation rate, and a stubborn unemployment problem. Equally important, it entered a nation which had a long history of racial and ethnic discrimination and which had just emerged from a bitter and unsuccessful war in Southeast Asia. As in the post-World War I period, the United States appears to be in retreat from a period of intense and overly optimistic preoccupation with domestic reform; crusades begun in the 1960's against inequality, poverty, and pollution are no longer national priorities. As in the early 1920's, a period of intense restrictionist activity, the nation seems to be seeking a return to a not very clearly defined but socially and politically conservative "normalcy." Since immigration policy in the past has been a reaction to the hopes and fears of the policymakers as well as to the objective situation presented by the immigrants, the impact of these factors on the current policy debate cannot be ignored.

The debates described earlier took place in the absence of comprehensive federal immigration legislation; federal action to limit immigration was itself the issue. This is no longer the case. Since Congress placed the numerical limit on total immigration in 1921, a return to unlimited immigration has never been seriously considered. Instead, debate has focused on the setting of the limit, on the priorities within that limit, and on the admission of refugees beyond that limit.

The legal context for the current immigration debate is the Immigration Act of 1965.113 Reflecting the civil rights movement's campaign against racism, the pluralistic views of John F. Kennedy, and Cold War concerns about world opinion, the Immigration Act of 1965 eliminated the discriminatory national origins quotas that had controlled immigration since the 1920's. All nations were now treated equally, with immigration priority given to relatives of persons already in the United States and to persons with special skills. ${ }^{114}$ Reflecting voters' concerns about American jobs, Congress placed a limit of 290,000 on total immigration including, for the first time, immigration from the Western Hemisphere. All persons not entering as relatives or as refugees were required to obtain a labor clearance certifying that American workers were not available for their jobs and that their presence would not reduce prevailing wages or diminish working conditions.

Critics of the Immigration Act of 1965 have complained that its priority system drains skilled and professional persons from Third World countries which need their services, and that current discrimination based on past educational opportu-

111. See generally id.

112. Id. at 11 .

113. Immigration and Nationality Act of 1965, Pub. L. No. 89-236, 79 Stat. 111 (codified as amended in scattered sections of 8 U.S.C. (1976)).

114. The Immigration Act of 1965 amended the McCarran-Walter Act of 1952, Pub. L. No. 82-414, 66 Stat. 163 (codified as amended at 8 U.S.C. $\S \S 1101-1503$ and in scattered sections of $18,22,31$, and 50 App. U.S.C. (1976)). For a summary of the legislative history of the 1965 Act, see E. HUTCHINSON, supra note 2, at 366-79. For further analysis of both acts, see C. KEely, U.S. IMmigration: A POLICY ANALYSIS 15-23 (1978). 
nities is no more just than past discrimination based on race and national origin. Most of the opposition to current immigration policy, however, focuses on immigrants other than the 290,000 admitted annually under the Immigration Act of 1965; it focuses on the refugees and undocumented migrants who constitute the vast majority of current immigrants. Since World War II large numbers of refugees have entered the country. These have included Hungarian freedom fighters, Dutch refugees from Indonesia, Chinese Nationalists, Cubans, and in recent years, Southeast Asians. Because of the unavailability of sufficient visas under general immigration legislation, refugees have entered under special acts of Congress or, more recently, under the Attorney General's emergency power to admit "parolees," subject to later approval by Congress. ${ }^{115}$ Critics have expressed concern that increased use of the Attorney General's parole power circumvents Congressional control of immigration. ${ }^{116}$

Illegal immigrants include students, tourists, and other temporary residents of many nationalities who "disappear" permanently into American society. The majority, however, are Mexican laborers who regularly cross the loosely guarded border to work on the farms, ranches, and factories of the Southwest. In 1978 the Congressional Commission on Immigration and Refugee Policy estimated that there were between $3,000,000$ and $6,000,000$ undocumented migrants in this country. ${ }^{117}$ The exact number is difficult to ascertain. Like the unskilled European laborers at the turn of the century, many Mexican migrants work here for a brief period and then return home to stay. Others shuttle back and forth repeatedly.

Despite changes in the times, the nation, and the composition of the latest wave of immigrants, much of the current policy debate has a familiar ring to persons acquainted with immigration history. The post-World War II consensus for a generous policy rested on the familiar combination of humanitarian and political considerations. The United States wished to reunite divided families and to provide refuge for the oppressed-especially, given Cold War priorities, the oppressed from Communist-controlled nations. The abandonment of racist national origins quotas in 1965 reflected both conscience and the Cold War priority of courting the good opinion of uncommitted and Third World countries.

As new Asian and Hispanic ethnic communities became conspicuous in American cities, turn-of-the-century views on the benefits of cultural pluralism were heard again. These views were reinforced and updated by the "new ethnicity" of the early 1970's. City dwellers enjoyed the new ethnic shops and restaurants, and officials were delighted when newly arrived ethnic groups restored deteriorated neighborhoods. ${ }^{118}$

With the energy crisis and recession of the mid-1970's, the national mood became less hospitable, while the immigrants became more numerous. The gov-

115. See E. Hutchinson, supra note 2, at 561-63.

116. C. KEELY, supra note 114, at 69-70.

117. See id. at 51 ; Reimers, supra note 1 , at 6-7.

118. See Fitzpatrick \& Parker, Hispanic Americans in the Eastern United States, in AMERICA AS A MULticultural Society 110 (454 Annals, M. Gordon ed. 1981). 
ernment recognized a special obligation to Vietnamese refugees, admitting 150,000 in 1975 alone. Their admission was controversial, however; the country was in a major recession, and both advocates and opponents of the recent war found its refugees suspect. A number of Governors and Congressmen made it clear that they did not want many refugees in their own states, and public opinion polls in 1975 and 1976 showed most Americans to be against admission of the Vietnamese. ${ }^{119}$ Objections were also raised to the arrival of flotillas of undocumented Cubans and Haitians in 1980 and $1981,{ }^{120}$ and to the continuing influx of illegal migrants from Mexico. ${ }^{121}$ These objections were political as well as economic. A nation still smarting from its long and humiliating inability to extricate its citizens taken hostage in Iran was sensitive to charges of weakness in its dealings with foreign states. In its early months, the Reagan administration seemed determined to assert a position of mastery in dealing with foreign nations-and with illegal immigrants from foreign nations.

"We have lost control of our borders," said Attorney General Smith in 1981, proposing to reassert control through increased border patrols, new detention facilities along the borders, and fines for employers of undocumented workers. ${ }^{122}$ The continuing need for inexpensive labor in the Southwest was to be met by the institution of a "guest" or temporary worker program for Mexican labor. ${ }^{123}$ The Reagan administration proposed an amnesty for Mexicans who had entered the country illegally before January 1, 1980, accompanied by a ten-year waiting period during which these aliens would pay taxes but remain ineligible for welfare, food stamps, and unemployment benefits. ${ }^{124}$ These new proposals reflect America's continued ambivalence over immigration; immigrants are wanted for their cheap labor but feared as a potential economic burden.

Given the uncertain state of the American economy, it is not surprising that economic issues are prominent in the current debate. As in the past, it is widely argued that immigrant labor takes jobs needed by unemployed Americans. Foreign workers, the argument goes, accept inferior wages, benefits, and working conditions, thus driving out American labor by unfair competition. In some quarters, the economic debate over immigration has become more heated. American blacks rioted to protest what they saw as the unfair economic advantages enjoyed by Cubans in Florida. Vietnamese shrimp fishermen were physically attacked by native-born competitors in the Gulf of Mexico. Blacks, Hispanics, and Indochinese competed for jobs and housing in Los Angeles County.

Since the American economy is no longer expanding as it was at the time of

119. See Refugees: A Cool and Wan Reception, Time, May 12, 1975, at 24, 26; Schaefer \& Schaefer, Reluctant Welcome: U.S. Response to Vietnamese Refugees, 4 New CoMmunity 366-70 (1976). (1982).

120. See S. Weintraub \& S. Ross, "Temporary" alien Workers in the United States 6

121. See id. at 66-68.

122. Buffalo Courier Express, Aug. 2, 1981, at C2, col. 1-2.

123. Similar "bracero" programs were instituted during the 1940's and carried through the early 1950's, but abruptly ended with the mass deportation of undocumented workers in 1954 . For a recent account, see J. Garcia, Operation Wetback: The Mass Deportation of Mexican Undocumented Workers IN 1954 (1980); see also M. Herrera-Sobek, The BraCero EXPerience (1979).

124. See S. Weintraub \& S. Ross, supra note 120 , at 82-83. 
earlier immigration debates, the economic argument for restriction appears more cogent than before. The lesson of the earlier debates, however, suggests caution. Current unemployment, like the unemployment of the past, is due to a variety of regional, social, and technological factors going beyond a simple oversupply of labor. The migration of industry from the Northeast and Great Lakes regions to the "sunbelt" began before the latest wave of immigration and will doubtless continue, leaving unemployment in its wake regardless of immigration policy. The plight of the "hard-core," native-born unemployed can be attributed to many factors independent of immigration. As in the past, today's immigrants often take jobs that are not wanted by Americans-migratory agricultural labor, for example, or menial service positions. The deportation of undocumented Mexicans or Haitians may be desired for other reasons, but its positive effect on the employment prospects of automobile workers in Detroit or Buffalo is dubious. It is equally questionable whether the barring of immigrant physicians would result in more native-born minority physicians-especially with the costs of higher education rising, federal loan programs for students being cut, and affirmative action no longer a priority.

The economic argument introduced by the New England Puritans that immigrants use resources needed by others has been revived in a nation coming to the painful realization that its resources are not inexhaustible. With inflation shrinking real wages, hard-pressed taxpayers worry that immigrants may swell the welfare rolls. Local governments resist the expense of providing schools and other services for immigrants who cluster in their communities. ${ }^{125}$ Local officials worry about budget cuts and warnings about the need to replace federal aid with local responsibility. Like the eugenicists of the past, ecology-minded advocates of zero population growth (ZPG) deplore the birth rate among immigrants. Their concern is not that immigrants will pollute the national bloodline, but that they will make America too crowded. They also oppose immigration on the grounds that it will increase the population of a nation that already uses more than its share of the world's resources: "On the average, each of us consumes four times as much grain and 37 times as much energy as a Filipino. . . . There's no need for more Americans." 126

Fear that undocumented immigrants drain resources by going on welfare is unrealistic; illegal aliens often avoid applying for charity or welfare for fear of being deported. Fear that federal aid for areas of heavy immigrant settlement will fall victim to the administration's effort to balance the budget are more realistic. However, experience with government assistance to both Hungarian refugees and the earlier arrivals from Cuba, who have moved rapidly into the American mainstream, suggests that federal budget-cutting in this area would be shortsighted. Most immigrants come to the United States with the hope of improving their living standard, so it is likely that once here they will indeed increase their con3 .

125. Crewdson, Access to Free Education for Illegal Alien Children, N.Y. Times, Aug. 26, 1980, at B10, col.

126. Zero Population Growth, 2 ZPG LoOks at Immigration 9-10 (1978), quoted in Keely, supra note 114 , at 49 . 
sumption of the world's resources. Advocates of ZPG may be partially reassured, however, by the historical experience that immigrant birthrates usually fall as economic and educational levels rise.

The shortage of resources worldwide may be real, but it is a less immediate problem for most Americans than is the shortage of resources at home. The prospect of immigrant groups competing with one another and with the native-born poor for diminishing urban resources that are likely to be further diminished because of economic recession and federal budget-cutting is uncomfortably reminiscent of competition for jobs at the turn of the century. At that time, employers pitted ethnic communities against one another to prevent the united action that might have improved conditions for all of them. Care must be taken that current economic frustrations are not vented in simplistic campaigns against immigration-as was the case in the late 19th century crusade against the Chinese in California.

Care must also be taken to avoid another error made repeatedly by restrictionists in the past: underestimation of the economic role of the immigrants as producers of wealth rather than merely as consumers of resources. Cuban immigrants have revitalized the economy of southern Florida, Koreans have built their own shopping area in Los Angeles, and immigrants furnish much of the workforce for the garment industry in New York, as well as for many industries in the Southwest. ${ }^{127}$ European labor at the turn of the century contributed more to the American economy than it extracted from it, although this was not clearly understood at the time. Similarly, today's undocumented migrants contribute more in labor and taxes than they take away in salaries and benefits, so that the economy gains rather than loses from their participation. ${ }^{128}$ Just as economic advances of the past often stemmed from the presence of immigrants to free American labor for more lucrative tasks, the availability of immigrants to do labor-intensive work today may foster new industrial growth. The issue then may become not how to keep immigrant labor out, but how to guarantee it a fair share of the wealth that it helps to produce.

Arguments that immigrants are dangerous to the nation's political stability-a staple of earlier immigration debates-are rarely heard today. Still, given today's political climate, there may be unspoken fears that larger minority populations will increase minority political activism, raising the possibility of disorders reminiscent of the 1960's. ${ }^{129}$ Immigration policy is entangled, moreover, in political battles between liberals and conservatives over America's posture toward controversial foreign regimes, especially rightwing dictatorships. In the Cold War context of the 1950's, refugees were defined as persons fleeing Communist regimes or the Middle East. ${ }^{130}$ This policy was continued by the Reagan administration, which identifies left- but not rightwing dictatorships as a threat to peace. Liberals

127. S. Weintraub \& S. Ross, supra note 120 , at 111 .

128. Id. at 39 .

129. See C. KEELY, supra note 114, at 52-53; Pachon \& Moore, Mexican Americans, in AMERICA AS A Multicultural Society 122 (454 Annals, M. Gordon ed. 1981).

130. Weintraub \& Ross, supra note 120 , at 5 . 
urge condemnation of rightwing governments for their human rights practices and argue that persons fleeing such governments, or even persons fleeing extreme poverty, should be granted refugee status. The Reagan administration's rejection of this claim is demonstrated by its denial of refugee status to Haitians.

The fate of the Haitians raises racial as well as political issues; black leaders in the United States have suggested that the treatment of the Haitians might have been different had these refugees been white. Overtly racist statements against immigration, so common at the turn of the century, are rarely heard in the current debate. Racial discriminaton was embodied in the nation's immigration laws until 1965, however; and the recent economically troubled times have been marked by an increase in the activities of overtly racist fringe groups such as the American Nazi Party and the Ku Klux Klan. ${ }^{131}$

Roughly coincident with these developments, a new cadre of academicians have published controversial findings stressing the controlling role of heredity in human evolution. Most notably, educational psychologist Arthur Jensen has claimed that I.Q. tests prove black children to be innately less intelligent than white children. ${ }^{132}$ Given these developments, and the fact that the current wave of predominantly Asian and Hispanic immigration is noticeably altering the ratio between mainstream whites and minorities, racism cannot be ruled out as a hidden motive in the current restrictionist movement.

Some commentators are suggesting that, because of their non-European background, current immigrants will be more difficult to assimilate than their earlier counterparts. ${ }^{133}$ Similar concerns were expressed about the assimilability of virtually every non-English group, from the colonial Germans to the 20th-century Italians, Poles, and Jews. In each case these fears proved unfounded.

Like other immigrants, those from the Third World have assimilated and will continue to assimilate at varying rates, depending on their social class, education, and skills before immigration, and on the economic opportunities and outside help available to them and the level of prejudice they encounter after arrival. A large proportion of recent immigrants from Asia had been educated, often in the professions, before their arrival, and therefore have moved easily into the American middle class. The Korean community, $90 \%$ of whom have resided here for fewer than fifteen years, have largely adjusted to life in their adopted country. It has been suggested that "as a whole the [Vietnamese] refugees may be better prepared to cope with life in America than the Jewish, Japanese, Korean, and [F]ilipino

131. See generally Turner, Stanton, Vahala \& Williams, The Klan Today, in Southern Poverty LAW Center, The Ku Klux Klan: A History of Racism and Violence 48 (1982).

132. Jensen, How Much Can We Boost IQ and Scholastic Achievement?, 39 Harvard EduC. ReV. 1 (1959). Jensen found almost the same I.Q. gap between blacks and whites that educational psychologists found in the 1920's between children of southern and eastern European immigrants and mainstream American children. See supro notes 79-80 and accompanying text.

Jensen's findings, like those cited by eugenicists in the 1920's, have generated considerable controversy. See, e.g., R. Herrnstein, I.Q. IN The Meritocracy (1973); P. Sanday, On the Causes Of IQ Differences Between Groups and the IMPlications for SOCIAL POlicy (1972).

133. See, e.g., Buffalo Courier Express, Sept. 13, 1981, at C5, col. 8. 
laborers of yesteryear."134

Concerns about the nation's rapidly growing Hispanic community often focus on problems of language rather than those of race or ethnicity. Protests against continued immigration of Cubans, Mexicans, and other Hispanics often reflect fear that Spanish will become a second language in the United States. ${ }^{135}$ Like protests against the widespread use of German in colonial Pennsylvania, these objections reflect both an English language chauvinism and a fear that the foreign language speakers will destroy the cultural integrity of an English-speaking nation. If the children or grandchildren of German-speaking immigrants in rural Pennsylvania learned English, however, it is scarcely conceivable that the descendants of Hispanic immigrants, aided by the electronic media if not by the public schools, will not do the same. Nor does immigration history lend support to the fear that immigrants who continue to speak their native language are more likely to be troublesome or dangerous to the rest of the nation.

Undoubtedly, this country must regulate immigration. With much of the world suffering from hunger or political oppression, the United States would probably be overwhelmed by immigrants if no numerical ceiling were set. Valid (though ever-changing) domestic and foreign policy reasons for admitting one individual or group as opposed to another do exist. The current situation-in which most immigrants enter the country outside the primary legislative apparatus, either as refugees or as illegals - suggests that systematic administrative and legislative adjustments are needed. Immigration history alone cannot suggest precisely what those adjustments should be, but it can warn against making policy based on racial and ethnic prejudice-covert as well as overt. Equally important, it can warn against using immigration restriction to "solve" social and economic problems whose solutions lie elsewhere.

134. Kitano, Asian Americans, in America as a Multicultural Society 137 (454 Annals, M. Gordon ed. 1981).

135. See Pachon \& Moore, supra note 129, at 121-22; see also C. KEELY, supra note 114, at 71. 